
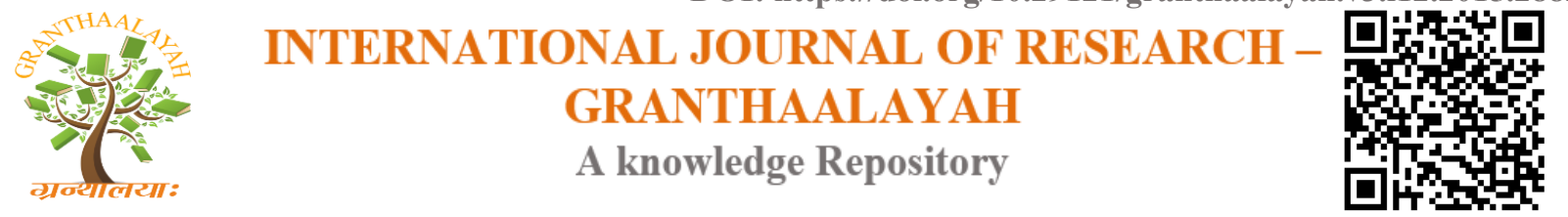

Science

\title{
REVIEW OF THE GREYWATER AND PROPOSED GREYWATER RECYCLING SCHEME FOR AGRICULTURAL IRRIGATION REUSES
}

\author{
Abeer Albalawneh ${ }^{* 1}$, Tsun-Kuo Chang ${ }^{2}$ \\ ${ }^{* 1,2}$ Department of Bioenvironmental Systems Engineering, National Taiwan University, Taipei \\ 10610, TAIWAN
}

\begin{abstract}
In this study, we reviewed greywater characteristics and various treatment technologies with the aim of coming up with the schematic of greywater recycling system designed specifically for restricted agricultural irrigation reuse. Characteristics of greywater are highly variable; greywater amount varies from $50 \%$ to $80 \%$ of the wastewater volume produced by households. All types of greywater show good biodegradability in terms of COD: BOD5 ratios. The ratio of $B O D 5 / C O D$ in greywater ranged from 0.31 to 0.71 . Most countries apply the same standards to reclaimed municipal wastewater as they do to greywater. However, some countries have established specialized standards for greywater reuse. Technologies used for greywater treatment are classified into physical, chemical, biological, and natural systems, or a combination of these. Using physical greywater treatment processes solely as the main treatment method is insufficient for greywater treatment, chemical greywater treatment processes are attractive for single household low-strength greywater treatment systems, as the variability in the strength and flow of the greywater did not affect their treatment performance. Constructed wetland can be regarded as the most environmentally friendly and cost-effective technology for greywater treatment and reuses. Finally, the study suggests the possible greywater recycling scheme for agricultural irrigation reuse purposes.
\end{abstract}

Keywords:

Greywater quantity; greywater treatment; greywater quality; greywater irrigation.

Cite This Article: Abeer Albalawneh and Tsun-Kuo Chang, "REVIEW OF THE GREYWATER AND PROPOSED GREYWATER RECYCLING SCHEME FOR AGRICULTURAL IRRIGATION REUSES" International Journal of Research - Granthaalayah, Vol. 3, No. 12(2015): 16-35. DOI: 10.29121/granthaalayah.v3.i12.2015.2882.

\section{INTRODUCTION}

As the world's freshwater supply becomes increasingly scarce, increased attention towards alternative water resources has become necessary. Water reuse is gaining significant momentum in discussions about sustainable water resource management, green economies, and urban planning. Greywater reuse is a promising alternative water source, which could be exploited on 
a continuous basis and treated for non-potable uses (Chong et al., 2015). Increasingly, greywater use is seen as an essential component of local and national efforts to adapt to climate change, enhance food security, extend potable water supply, and reduce pollutants in the environment (Drechsel et al., 2015).

Greywater treatment methods vary based on site conditions and greywater characteristics. The design of a greywater treatment system primarily depends on water quality, the quantity to be treated, and the reuse applications. A wide range of greywater treatment technologies have been applied and examined and they produce effluents with different qualities. In this study, we reviewed greywater characteristics and various treatment technologies with the aim of coming up with a schematic of greywater recycling system designed specifically for restricted agricultural irrigation. The issues considered in this study include greywater characteristics, guidelines, current treatment technology performance.

\section{GREYWATER CATEGORIES}

Greywater is defined as wastewater that includes water from baths, showers, hand basins, washing machines, dishwashers, and kitchen sinks, but excludes streams from toilets (Jefferson et al., 2000; Eriksson et al., 2002; Friedler and Hadari, 2006; WHO-guidelines, 2006). Some authors exclude kitchen wastewater from the other greywater streams (Christova-Boal et al., 1996; Al-Jayyousi, 2003; Ghunmi, 2009). Wastewater from the bathroom, including showers and tubs, is termed light greywater (Friedler and Hadari, 2006). Greywater that includes more contaminated waste and from laundry facilities, dishwashers and, in some instances, kitchen sinks is called dark greywater (Birks and Hills, 2007). Some greywater sources and their constituents are presented in Figure 1.

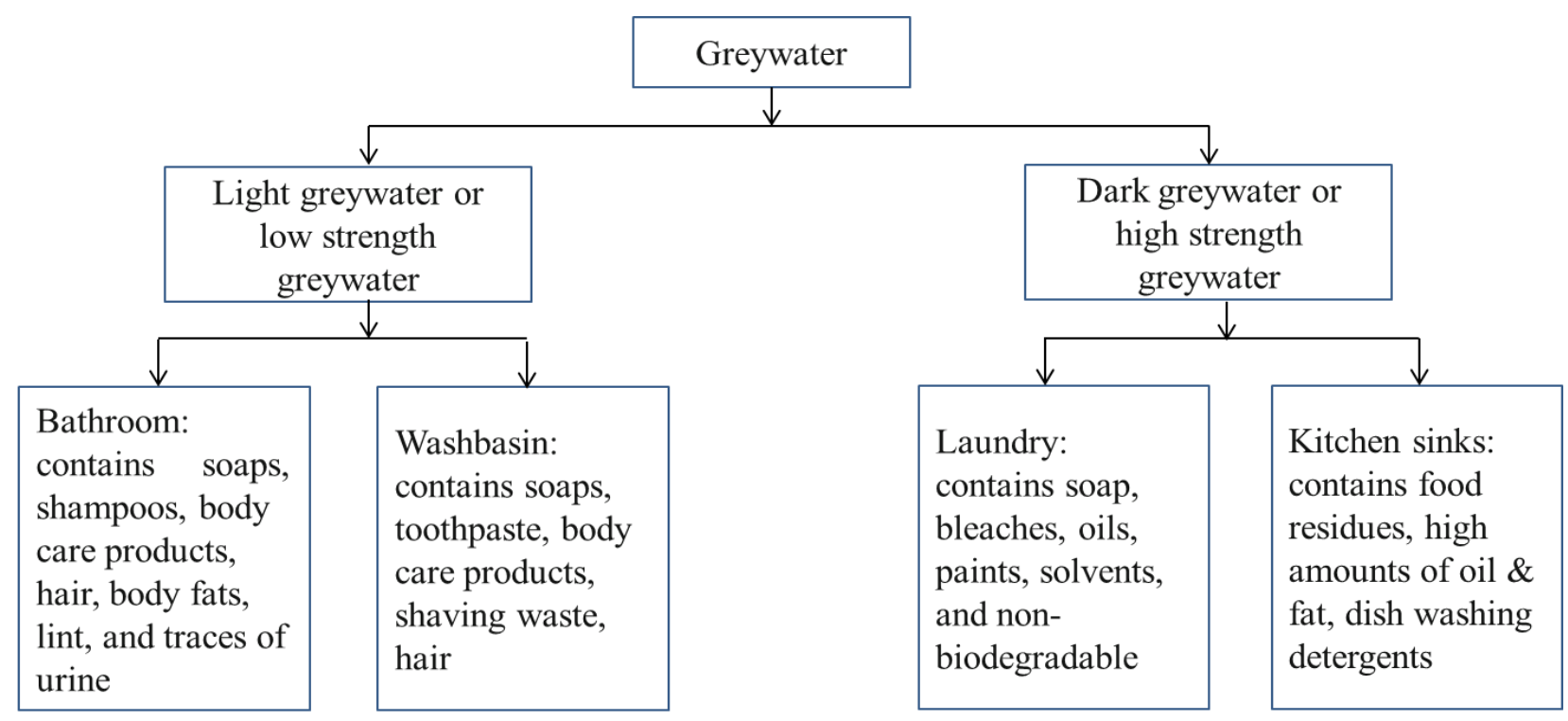

References:(Noah, 2002; Morel and Diener, 2006; Ghaitidak and Yadav, 2013)

Figure 1: Greywater sources and their constituents. 


\section{CHARACTERISTICS OF GREYWATER}

\subsection{QUANTITY OF GREYWATER}

Water consumption always depends on the quality of life standards and availability of resources. The quantity of greywater generation depends on the total water consumption, living standard, population structures (i.e., age, gender), resident habits, and water installations of a given population (Morel and Diener, 2006; Ghaitidak and Yadav, 2013). Therfore, greywater varies from $50 \%$ to $80 \%$ of the wastewater volume produced by households (Jenssen and Vråle, 2003; Flowers, 2004), and over $90 \%$ if vacuum toilets are installed Leal et al. (2011). The typical volume of greywater varies from 90 to $120 \mathrm{l} / \mathrm{p} / \mathrm{d}$, however the volume of greywater in low income countries that experience chronic water shortages can be as low as 20-30 1/p/d (Morel and Diener, 2006). The quantity of greywater also varies between urban and rural area, as shown in Figure 2.

The published literature indicates that about $27 \%$ of greywater originates from the kitchen sink and dishwasher, $47 \%$ originates from the wash basin, bathroom, and shower, and $26 \%$ originates from laundry and the washing machine.(Jamrah et al., 2006; Al-Mughalles et al., 2012; Ghaitidak and Yadav, 2013).

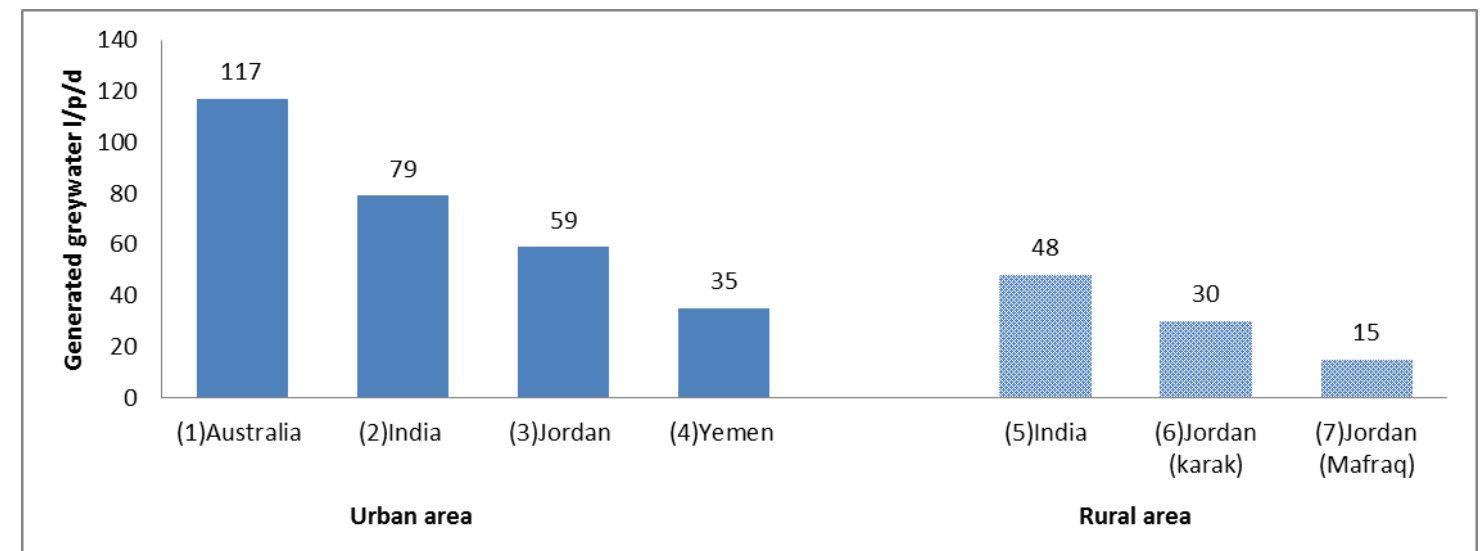

References: (1):(Perth, 2008), (2\&5):Harikumar and Mol (2012), (3):Jamrah et al. (2006), (4):Al-Mughalles et al. (2012), (6):Al-Hamaiedeh and Bino (2010), (7):Halalsheh et al. (2008).

Figure 2: The volume of greywater generated in various rural and urban areas

\subsection{QUALITY OF GREYWATER}

Grey water is generated as a result of the living habits of the people involved. Therefore, its characteristics are highly variable and influenced by lifestyle, the social and cultural behavior of the residents, the availability of water, and the consumption amount (Eriksson et al., 2002; Jefferson et al., 2004; Uddin et al., 2015). Greywater includes different ranges of organic matters (Halalsheh et al., 2008), suspended solids, heavy metals (Palmquist and Hanæus, 2005), inorganic ions (Eriksson and Donner, 2009), and E.coli (Winward et al., 2008). Although the levels of these pollutants in greywater are presumed to be lower compared to wastewater, many studies have observed the opposite (Halalsheh et al., 2008; Bino et al., 2010; Dalahmeh et al., 2011). For example, BOD5 in composite greywater samples collected from rural villages in Jordan reached 
1,400 mgL-1 in some cases, which is even higher than the concentration reported in concentrated wastewater (Assayed, 2014).

The physical and chemical characteristics of greywater have been widely discussed in the academic literature. Tables 1,2, and 3 show the the characteristics of dark and light greywater from several countries. Results in these tables indicate that greywater parameters are highly variable, as expected from daily or seasonal fluctuations and the above discussed variations in quantity and quality. The ranges of electrical conductivity, turbidity, and suspended solids for dark greywater are 190-1,830 $\mu \mathrm{S} \mathrm{cm}-1,19-444 \mathrm{NTU}$, and 12-315 mgL-1, respectively, while for light greywater these ranges are 14-921 $\mu \mathrm{Scm}-1,12.6-375 \mathrm{NTU}$, and 29-505 mgL-1, respectively (Boyjoo et al., 2013). The high-end range of electrical conductivity arises in the water-scarce countries of Jordan, Spain, and Morroco. The BOD and COD concentrations are within the ranges 48-1,056 and 50-2,568 mgL-1, respectively, for dark greywater, and 20-300 and 55-633 mgL-1, respectively, for light greywater (Boyjoo et al., 2013). Kitchen greywater contains biodegradable dissolved food particles that contribute to the BOD, while the high COD concentration in dark greywater is probably due to the presence of detergents in laundry powders and dishwashing liquids (Boyjoo et al., 2013). The highest BOD and COD values registed in Jordan are 1,056 mgL-1 and 2,568 mgL-1, respectively. Morover, kitchen and laundry greywater are higher in both organics and physical pollutants compared to bathroom greywater. Bathroom and laundry greywater are less contaminated by microorganisms, compared to kitchen greywater. Casanova et al. (2001) found that kitchen water contributes 3-4 logs to the fecal greywater load, which might be due to the presence of large amounts of easily biodegradable organic substances in kitchen greywater. Kitchen greywater is also more contaminated by thermal-tolerant coliforms than other greywater streams (WHO-guidelines, 2006; Li et al., 2009; O'Toole et al., 2012). WHO-guidelines (2006) consider faecal contamination to be the main hazard of greywater, and the high numbers of bacteria imply a greater chance for infection and illness that result from human contact with greywater. Faecal contamination normally comes from washing feacally-contaminated clothes, child care, and washing raw meats (Casanova et al., 2001; O’Toole et al., 2012) .

Tables 1, 2, and 3 also show that the nutrients $\mathrm{N}$ and $\mathrm{P}$ are also higher in dark greywater (21-57.7 and 0.062-42 mgL-1, respectively) compared to light greywater (4.1-16.4 and 0.11-1.8 mgL-1, respectively), due to kitchen greywater and phosphates from laundry detergents (Boyjoo et al., 2013). Elemental concentrations also vary according to the water quality and plumbing conditions that prevail in each country. However, it is well known that laundry detergents are a source of heavy metals such as $\mathrm{Cd}, \mathrm{Cu}, \mathrm{Pb}, \mathrm{Cr}$, and $\mathrm{Zn}$. The amounts of $\mathrm{B}$ in one Indian study and the $\mathrm{Zn}$ and $\mathrm{Cu}$ in an Australian study were 1.5, 6.3, and $0.27 \mathrm{mgL}-1$, respectively. Boyjoo et al. (2013) considered these values to be too high to use the resultant greywater for long-term irrigation, while the concentration of $\mathrm{Al}$ reported in the Australian study (21 mgL-1) is too high for any type of irrigation.

Biodegradability refers to the ability of bacteria to digest or decompose the organic matter in greywater and convert it to $\mathrm{CO} 2$ and $\mathrm{H} 2 \mathrm{O}$ (Metcalf and Eddy, 1991). It is a very important aspect to consider, since it determines the effectiveness of biological treatment in greywater. All types of greywater show good biodegradability in terms of COD: BOD5 ratios (Li et al., 2009). The ratio of $\mathrm{BOD} 5 / \mathrm{COD}$ in greywater ranged from 0.31 to 0.71 , and the average was $0.45 \pm$ 
0.13, which means that almost half of the organic matter in greywater is biodegradable (Halalsheh et al., 2008; Knerr et al., 2008).

Table 1: The characteristics of light greywater from specific countries with their greywater resources*

\begin{tabular}{|c|c|c|c|c|c|c|c|c|c|c|}
\hline \multirow{2}{*}{ Parameters } & \multirow{2}{*}{ Unites } & Australia $^{(1)}$ & Taiwan $^{(2)}$ & Korea $^{(3)}$ & France $^{(4)}$ & Germany $^{(5)}$ & $\mathrm{UK}^{(6)}$ & Spain $^{(7)}$ & Morocco $^{(8)}$ & $\mathrm{Oman}^{(9)}$ \\
\hline & & bath & shower & Floor cleaning & Bath+ shower & Bath+ shower & $\begin{array}{l}\text { Bath+ } \\
\text { shower+washbasin }\end{array}$ & $\begin{array}{l}\text { Bath+ } \\
\text { shower+washbasin }\end{array}$ & shower & $\begin{array}{l}\text { shower+ } \\
\text { washbasin }\end{array}$ \\
\hline $\mathrm{pH}$ & & $6.4-8.1$ & $6.5-7.5$ & 7.27 & 7.58 & & $6.6-7.3$ & $6.8-7.6$ & 7.6 & $7.1-7.4$ \\
\hline $\mathrm{EC}$ & $\mu \mathrm{S} \mathrm{cm}{ }^{-1}$ & $82-250$ & & 194 & 468 & & & 921 & $645-855$ & $14-15$ \\
\hline Turbidity & NTU & $60-240$ & 43.1 & 12.6 & 150 & & $35-42$ & $20-38.8$ & 29 & $133-375$ \\
\hline TSS & $\mathrm{mg} \mathrm{L}^{-1}$ & $48-120$ & 29 & & 125 & & 29 & $32.2-44$ & & $353-505$ \\
\hline $\mathrm{NO}_{3}^{-}$ & $\mathrm{mg} \mathrm{L}^{-1}$ & $<0.05-0.2$ & & & & & $3.9-7.5$ & & 0 & $10.2-28.7$ \\
\hline Ammonia $\left(\mathrm{NH}_{3} / \mathrm{NH}_{4}{ }^{+}\right)$ & $\mathrm{mg} \mathrm{L}^{-1}$ & $<0.1-15$ & 0.146 & & & & $0.7-1$ & & $6.6-11.8$ & \\
\hline $\begin{array}{l}\text { Total } \quad \text { Kjeldahl } \\
\text { nitrogen (TKN) }\end{array}$ & $\mathrm{mg} \mathrm{L}^{-1}$ & $4.6-20$ & & & & & & & $11.9-15.2$ & \\
\hline Total nitrogen (TN) & $\mathrm{mg} \mathrm{L}^{-1}$ & & & & 9.5 & $5-10$ & $7.6-16.4$ & $4.1-11.4$ & & \\
\hline Phosphate (PO4 $\left.4^{3-}\right)$ & $\mathrm{mg} \mathrm{L}^{-1}$ & & & & & & $0.5-1.3$ & & 1 & \\
\hline $\begin{array}{ll}\begin{array}{l}\text { Total } \\
\text { (TP) }\end{array} & \text { phosphorus } \\
\end{array}$ & $\mathrm{mg} \mathrm{L}^{-1}$ & $0.11-1.8$ & & & 0.42 & $0.2-0.6$ & & & $0.98-1.6$ & \\
\hline $\mathrm{BOD}_{5}$ & $\mathrm{mg} \mathrm{L}^{-1}$ & $76-200$ & 23 & & 240 & $50-300$ & $20-166$ & & $53-59$ & $42.1-130$ \\
\hline COD & $\mathrm{mg} \mathrm{L}^{-1}$ & & 55 & & 399 & $100-633$ & $86-575$ & $72.7-171$ & $109-122$ & $58-294.3$ \\
\hline TOC & $\mathrm{mg} \mathrm{L}^{-1}$ & & & & 50.6 & $26-95$ & $12-56$ & $41-58$ & & $70.2-83.5$ \\
\hline Surfactant & $\mathrm{mg} \mathrm{L}^{-1}$ & & & & 6.8 & & & & & $14.9-41.9$ \\
\hline Total coliform & $\mathrm{CFU} / 100 \mathrm{~mL}$ & 500 to $2.4 \times 10^{7}$ & & 0 & & 10 to $1.0 \times 10^{3}$ & 4.0105 & & & $>200.5$ \\
\hline faecal coliform & $\mathrm{CFU} / 100 \mathrm{~mL}$ & 170 to $3.3 \times 10^{3}$ & & & $3.42 \times 10^{5}$ & $0.1-10$ & & & $\begin{array}{l}1.4 \times 10^{3} \text { to } \\
2.48 \times 10^{5}\end{array}$ & \\
\hline Escherichia coli & CFU $/ 100 \mathrm{~mL}$ & 79 to $2.4 \times 10^{3}$ & $5.1 \times 10^{3}$ & & $4.76 \times 10^{5}$ & & & & & $>200.5$ \\
\hline
\end{tabular}

Table 2: The characteristics of dark greywater from specific countries with their greywater resources*

\begin{tabular}{|c|c|c|c|c|c|c|c|c|c|c|}
\hline \multirow{2}{*}{ Parameters } & \multirow{2}{*}{ Unites } & Australia $^{(1)}$ & Japan $^{(2)}$ & Korea $^{(3)}$ & India $^{(4)}$ & Brazil $^{(5)}$ & Germany $^{(6)}$ & Turkey $^{(7)}$ & Jordan $^{(8)}$ & $\operatorname{Oman}^{(9)}$ \\
\hline & & laundry & kitchen & $\begin{array}{l}\begin{array}{l}\text { kitchen } \\
\text { +shower }\end{array} \\
\end{array}$ & Mixed & Mixed & Mixed & Mixed & Mixed & laundry \\
\hline $\mathrm{pH}$ & & $9.3-10$ & & & 7.3-8.1 & & $6.9-8.1$ & $7.1-7.2$ & 6.35 & 8.3 \\
\hline $\mathrm{EC}$ & $\mu \mathrm{S} \mathrm{cm}^{-1}$ & $190-1400$ & & & 489-550 & & & 401-495 & 1830 & \\
\hline Turbidity & NTU & $50-210$ & & $19-84.8$ & $20.6-38.7$ & 254 & & & & 444 \\
\hline TSS & $\mathrm{mg} \mathrm{L}^{-1}$ & $88-250$ & 105 & $30-130$ & $12-17.6$ & 120 & & $48-54$ & 168 & 315 \\
\hline $\mathrm{NO}_{3}{ }^{-}$ & $\mathrm{mg} \mathrm{L}^{-1}$ & $0.1-0.31$ & & & $0.5-0.63$ & 0.05 & & $0.13-1.3$ & & 25.8 \\
\hline Ammonia $\left(\mathrm{NH}_{3} / \mathrm{NH}_{4}^{+}\right)$ & $\mathrm{mg} \mathrm{L}^{-1}$ & $<0.1-1.9$ & & & & 2.4 & & $1.2-1.3$ & 75 & \\
\hline $\begin{array}{l}\text { Total } \quad \text { Kjeldahl } \\
\text { nitrogen }(\mathrm{TKN})\end{array}$ & $\mathrm{mg} \mathrm{L}^{-1}$ & $1.0-40$ & & & & & 27.2 & $7.6-9$ & 128 & \\
\hline Total nitrogen (TN) & $m g L^{-1}$ & & 21 & & $42.8-57.7$ & 8.8 & $9.7-16.6$ & & & \\
\hline Phosphate $\left(\mathrm{PO}^{3-}\right)$ & $\mathrm{mg} \mathrm{L}^{-1}$ & & & & $1.52-3.36$ & 5.6 & 9.8 & & & \\
\hline $\begin{array}{l}\text { Total phosphorus } \\
\text { (TP) }\end{array}$ & $\mathrm{mg} \mathrm{L}^{-1}$ & $0.062-42$ & 4 & & & & $5.2-9.6$ & $7.2-7.3$ & 19.5 & \\
\hline
\end{tabular}




\begin{tabular}{|c|c|c|c|c|c|c|c|c|c|c|}
\hline $\mathrm{BOD}_{5}$ & $\mathrm{mg} \mathrm{L}^{-1}$ & $48-290$ & 477 & & $56-100$ & 435 & & $90-116$ & 1056 & 179.7 \\
\hline COD & $\mathrm{mg} \mathrm{L}^{-1}$ & & 271 & $50-400$ & $244-284$ & 646 & 640 & $177-277$ & 2568 & 231.3 \\
\hline TOC & $\mathrm{mg} \mathrm{L}^{-1}$ & & & & & & $80.2-93.8$ & & & 174.6 \\
\hline Surfactant & $\mathrm{mg} \mathrm{L}^{-1}$ & & & & & & & & & 118.3 \\
\hline Total coliform & $\mathrm{CFU} / 100 \mathrm{~mL}$ & $\begin{array}{l}2.3 \times 10^{3} \text { to } \\
3.3 \times 10^{5}\end{array}$ & & $1.2 \times 10^{3}$ & $3.74 \times 10^{4}$ to $3.8 \times 10^{4}$ & $5.4 \times 10^{8}$ & & $1.36 \times 10^{4}$ & $1.0 \times 10^{7}$ & $>200.5$ \\
\hline faecal coliform & $\mathrm{CFU} / 100 \mathrm{~mL}$ & $\begin{array}{l}110 \text { to } \\
1.09 \times 10^{3}\end{array}$ & & $4.0 \times 10^{3}$ & $\begin{array}{l}3.48 \times 10^{4} \text { to } \\
3.56 \times 10^{4}\end{array}$ & $5.4 \times 10^{6}$ & $\begin{array}{l}7.5 \times 10^{3} \text { to } \\
2.6 \times 10^{5}\end{array}$ & $\begin{array}{l}3.57 \times 10^{3} \text { to } \\
1.1 \times 10^{4}\end{array}$ & $3.0 \times 10^{5}$ & \\
\hline Escherichia coli & CFU /100mL & & & & & & & & $2.0 \times 10^{5}$ & $>200.5$ \\
\hline
\end{tabular}

Table 3: The characteristics of low and high strength greywater from specific countries with their greywater resources *

\begin{tabular}{|c|c|c|c|c|c|c|c|}
\hline \multirow{3}{*}{$\begin{array}{l}\text { Elements } \\
\mathrm{mg} \mathrm{L}^{-1}\end{array}$} & \multicolumn{5}{|c|}{ dark greywater } & \multicolumn{2}{|c|}{ light greywater } \\
\hline & Australia $^{(1)}$ & India $^{(2)}$ & Holland $^{(3)}$ & $\mathrm{Oman}^{(4)}$ & Sweden $^{(5)}$ & Australia $^{(8)}$ & $\mathrm{Oman}^{(9)}$ \\
\hline & laundry & Mixed & Mixed & laundry & Mixed & Bath & shower+ washbasin \\
\hline $\mathrm{Ca}$ & $3.9-12$ & - & $30-63.2$ & 18.7 & $31.6-38$ & $3.5-7.9$ & $15.8-19.7$ \\
\hline $\mathrm{Mg}$ & $1.1-2.9$ & - & $10-18.4$ & 60.8 & $5.3-6.22$ & $1.4-2.3$ & $21-56.1$ \\
\hline $\mathrm{Na}$ & $49-480$ & $43.8-48.1$ & $123.1-144$ & 667 & 61.4-92.4 & 7.4-18 & $149-184.5$ \\
\hline $\mathrm{K}$ & $1.1-17$ & 8.3-15.2 & 12 & 23.4 & $7.69-8.85$ & $1.5-5.2$ & $5.5-43.1$ \\
\hline B & - & $1.3-1.5$ & $0.53-0.65$ & - & - & - & - \\
\hline $\mathrm{Fe}$ & $0.29-1$ & - & $0.7-0.74$ & ND & $0.18-0.57$ & $0.34-1.1$ & - \\
\hline $\mathrm{Zn}$ & $0.09-0.32$ & - & $0.05-0.13$ & 0.14 & $0.055-0.078$ & $0.2-6.3$ & $0.04-2.4$ \\
\hline $\mathrm{Cu}$ & $<0.05-0.27$ & - & $0.07-0.1$ & 0.0064 & $0.047-0.07$ & $0.06-0.12$ & $0-0.013$ \\
\hline $\mathrm{Pb}$ & - & - & - & 0.083 & $0.002-0.003$ & - & 0.062-0.104 \\
\hline $\mathrm{Ni}$ & - & - & - & 0.035 & $0.0045-0.028$ & - & 0.035 \\
\hline $\mathrm{Al}$ & $<1-21$ & - & $1.22-3.9$ & 0.081 & $1.48-3.39$ & $<1$ & $0.011-0.014$ \\
\hline $\mathrm{Ba}$ & - & - & - & ND & $0.016-0.022$ & - & 0 \\
\hline S & $9.5-40$ & - & $20-26.1$ & - & $22.4-25.7$ & $1.2-3.3$ & - \\
\hline $\mathrm{Si}$ & $3.8-49$ & - & 16.7 & - & - & $3.2-4.1$ & - \\
\hline $\mathrm{Cd}$ & $<0.01$ & - & - & ND & $6 \times 10^{-5}-16 \times 10^{-6}$ & $<0.01$ & - \\
\hline As & $0.001-0.007$ & - & - & 0 & ND & 0.001 & $0.015-0.03$ \\
\hline $\mathrm{Se}$ & $<0.001$ & - & - & - & - & $<0.001$ & - \\
\hline $\mathrm{Cl}$ & $9-88$ & 7.4-12.9 & 65.4 & - & - & $9-88$ & - \\
\hline
\end{tabular}

References:*Boyjoo et al. (2013) and the detailed references in Boyjoo's study were (1)+(8):Christova-Boal et al. (1996);(2) (Mandal et al., 2011); (3)(Leal et al., 2011) ;(4)+(9) (Prathapar et al., 2005)

Furthermore, the ratio of COD:N:P should be 100:20:1 to achieve efficient aerobic biodegradation (Metcalf and Eddy (1991). Kitchen greywater contributes the highest levels of organic substance, suspended solids, turbidity, and nitrogen. In contrast to other greywaters, kitchen greywater doesn't lack in $\mathrm{N}$ and $\mathrm{P}$ and has a COD:N:P ratio that closely aligns with the suggested ratio (Metcalf and Eddy, 1991; Li et al., 2009). Studies revealed that when kitchen water was excluded from the greywater stream, the average COD:N:P ratio was 100:3.5:1.6 
(Leal et al., 2011), which means that aerobic biological treatment would not be sufficiently effective due to a nitrogen deficit. Bathroom and laundry greywater are deficient in both $\mathrm{N}$ and $\mathrm{P}$ due to the exclusion of urine and feces. Knerr et al. (2008) and Lesjean and Gnirss (2006) have pointed out that mixed greywater has a balance COD:N:P ratio. In some cases, laundry greywater and mixed greywater are low in P due to the use of phosphorous-free detergent (Li et al., 2009). Much literature suggest that nutrients, particularly $\mathrm{N}$, should be added to enhance aerobic biological treatment processes for greywater (Jefferson et al., 2004). This could be achieved by allowing a small portion of kitchen water to get mixed with greywater (Li et al., 2009; Leal et al., 2011).

\section{GREYWATER REUSE GUIDELINES}

Reclaimed greywater should fulfill four criteria for reuse: hygienic safety, aesthetics, environmental tolerance, and economical feasibility (Nolde, 2000). The different reuse applications require different water quality specifications and thus demand different treatments, varying from simple processes to more advanced ones. Standard values for greywater monitoring vary by country. Very few reuse guidelines were designed with greywater recycling in mind (Li et al., 2009). In fact, most countries apply the same standards to reclaimed municipal wastewater as they do to greywater. However, some countries have established specialized standards for greywater reuse, such as the UK, Germany, Jordan, Japan, and Australia. Table 4 shows examples of standard values for greywater reuse from the UK, Japan, and Jordan. The differences observed between reuse criteria reflect differences in need, applications, and social factors (Pidou et al., 2007).

In 2006, the World Health Organization (WHO) published guidelines for greywater reuse. The publication was considered a significant shift in perspective towards greywater and wastewater reuse. The guidelines were based on the Stockholm framework, which combines risk assessment and risk management to control water-related diseases (Bartram et al., 2001). This guideline outlines microbiological requirements without considering the other physical and chemical parameters. Morover, the guidelines no longer look at water quality standards, but instead look at the appropriate health protection measures that are necessary to achieve health-based targets (WHO-guidelines, 2006). The WHO guidelines refer to treatment as one out of many options to reduce risk associated with greywater, rather than defining water treatment as the sole option for reusing of greywater. According to the WHO guidelines, health protection measures such as crop restriction, withholding periods between water application and harvest, and hygienic food handling and food preparation practices can lower the risks associated with greywater without going through the option of advance treatment. However, the application of these guidelines has faced some difficulties (Sinclair, 2010), as it needs full understanding and cooperation by all stakeholders to assess and manage the risks associated with the hazards. Therefore, in 2015 the WHO developed sanitation safety planning methods and published these methods in a manual that covered the safe use and disposal of wastewater, greywater, and excreta (WHO, 2015).

\section{GREYWATER TREATMENT TECHNOLOGIES}




\begin{tabular}{|c|c|c|c|c|c|c|c|c|}
\hline \multicolumn{9}{|c|}{ Table 4: Greywater reuse standard in the UK, Japan and Jordan } \\
\hline \multicolumn{9}{|c|}{ a) UK greywater standards (BS 8525) $)^{(1)}$} \\
\hline & & \multicolumn{3}{|l|}{ Spray application } & \multicolumn{4}{|c|}{ Non-spray application } \\
\hline \multicolumn{2}{|l|}{ Parameter } & \multicolumn{3}{|c|}{$\begin{array}{l}\text { Pressure washing, garden } \\
\text { sprinkler use and car }\end{array}$} & \multicolumn{2}{|c|}{ WC flushing } & Garden watering & $\begin{array}{l}\text { Washing } \\
\text { machine use }\end{array}$ \\
\hline \multicolumn{2}{|l|}{ E.coli (number/100ml) } & \multicolumn{3}{|l|}{ Not dtetected } & \multicolumn{2}{|l|}{250} & 250 & Not dtetected \\
\hline \multicolumn{2}{|c|}{ Intestinal enterococci (number/100ml) } & \multicolumn{3}{|l|}{ Not dtetected } & \multicolumn{2}{|l|}{100} & 100 & Not dtetected \\
\hline \multicolumn{2}{|l|}{ Turbidity NTU } & \multicolumn{3}{|l|}{$<10$} & \multicolumn{2}{|l|}{$<10$} & Not available & $<10$ \\
\hline \multicolumn{2}{|l|}{$\mathrm{pH}$} & \multicolumn{3}{|l|}{$5-9.5$} & \multicolumn{2}{|l|}{$5-9.5$} & $5-9.5$ & $5-9.5$ \\
\hline \multicolumn{2}{|l|}{ Residual Chlorine $\left(\mathrm{mg} \mathrm{L}^{-1}\right)$} & \multicolumn{3}{|l|}{$<2.0$} & \multicolumn{2}{|l|}{$<2.0$} & $<0.5$ & $<2.0$ \\
\hline \multicolumn{2}{|l|}{ Residual bromine ( $\mathrm{mg} \mathrm{L}^{-1}$ ) } & \multicolumn{3}{|l|}{0.0} & \multicolumn{2}{|l|}{0.0} & 0.0 & 0.0 \\
\hline \multicolumn{9}{|l|}{ b) Japan $^{(2)}$} \\
\hline \multicolumn{2}{|l|}{ Parameter } & \multicolumn{2}{|l|}{ Toilet flishing } & $\begin{array}{l}\text { Landscap } \\
\text { e } \\
\text { irrigation }\end{array}$ & \multicolumn{2}{|c|}{$\begin{array}{l}\text { Environmental } \\
\text { (aesthetic settling) }\end{array}$} & \multicolumn{2}{|c|}{$\begin{array}{lll}\text { Environmental (limited public } \\
\text { contact) }\end{array}$} \\
\hline $\mathrm{pH}$ & & $5.8-8.6$ & & $5.8-8.6$ & $5.8-8.6$ & & $5.8-8.6$ & \\
\hline Turbidity NTU & & Not unplesant & & $\begin{array}{l}\text { Not } \\
\text { unplesant }\end{array}$ & $\leq 10$ & & $\leq 5$ & \\
\hline $\mathrm{BOD}_{5}\left(\mathrm{mg} \mathrm{L}^{-1}\right)$ & & $\leq 20$ & & $\leq 20$ & $\leq 10$ & & $\leq 3$ & \\
\hline Residual Chlorine $\left(\mathrm{mg} \mathrm{L}^{-1}\right)$ & & & & $\leq 0.4$ & & & & \\
\hline Total Coliform (number/100ml) & & $\leq 1000$ & & $\leq 50$ & $\leq 1000$ & & $\leq 50$ & \\
\hline c) Jordanian greywater s & andar & Is (JS1767:2008) & & & & & & \\
\hline & Irrig & tion & & & & & & \\
\hline Parameter & $\begin{array}{l}\text { Tree } \\
\text { "rest }\end{array}$ & $\begin{array}{l}\text { and fodder irrigation } \\
\text { icted irrigation" }\end{array}$ & $\begin{array}{l}\text { Land } \\
\text { to be }\end{array}$ & $\begin{array}{l}\text { ape and ve } \\
\text { aten cooked }\end{array}$ & setables & vegetables to & eaten un cooked & Toilet flishing \\
\hline $\mathrm{BOD}_{5}\left(\mathrm{mg} \mathrm{L}^{-1}\right)$ & 300 & & 60 & & & 60 & & $\leq 10$ \\
\hline $\mathrm{COD}\left(\mathrm{mg} \mathrm{L}^{-1}\right)$ & 500 & & 120 & & & 120 & & $\leq 20$ \\
\hline $\operatorname{TSS}\left(\mathrm{mg} \mathrm{L}^{-1}\right)$ & 150 & & 100 & & & 50 & & $\leq 10$ \\
\hline $\mathrm{pH}$ & $6-9$ & & $6-9$ & & & $6-9$ & & $6-9$ \\
\hline $\mathrm{NO}_{3}\left(\mathrm{mg} \mathrm{L}^{-1}\right)$ & 50 & & 70 & & & 70 & & 70 \\
\hline $\mathrm{TN}\left(\mathrm{mg} \mathrm{L}^{-1}\right)$ & 70 & & 50 & & & 50 & & 50 \\
\hline Turbidity & 25 & & Not a & ailable & & Not available & & $\leq 5$ \\
\hline E.coli (number/100ml) & Not & pecified & 10 & & & 10 & & $<10$ \\
\hline Egg nematodes (number/1L) & $\leq 1$ & & $\leq 1$ & & & $\leq 1$ & & $\leq 1$ \\
\hline
\end{tabular}

Raw greywater treatment is a prerequisite for storage and use. Untreated greywater reuse would pose health risks to human beings and their environment, hence it should be treated to a higher standard before reusing (Winward et al., 2008; Li et al., 2009; Ghunmi et al., 2011). The aim of treatment is to overcome health, aesthetic, and technical problems (caused by pathogens, organic matter, and solids), and to meet reuse standards (Ghunmi et al., 2011). Numerous studies have been conducted on the treatment of greywater with different technologies that vary in both complexity and performance ( $\mathrm{Li}$ et al., 2009). Figure 3 shows that there has been an increasing number of publications in the last 17 years on this topic; this figure shows a strong bias in addressing the topic of greywater treatment, which represents about $69 \%$ of all published 
greywater research (studies were identified through a Web of Science search). However, studies that evaluate the appropriateness of technologies for greywater reuse are scarce (Li et al., 2009), and cost-effective treatment methods have not been developed so far (Jabornig and Podmirseg, 2015).

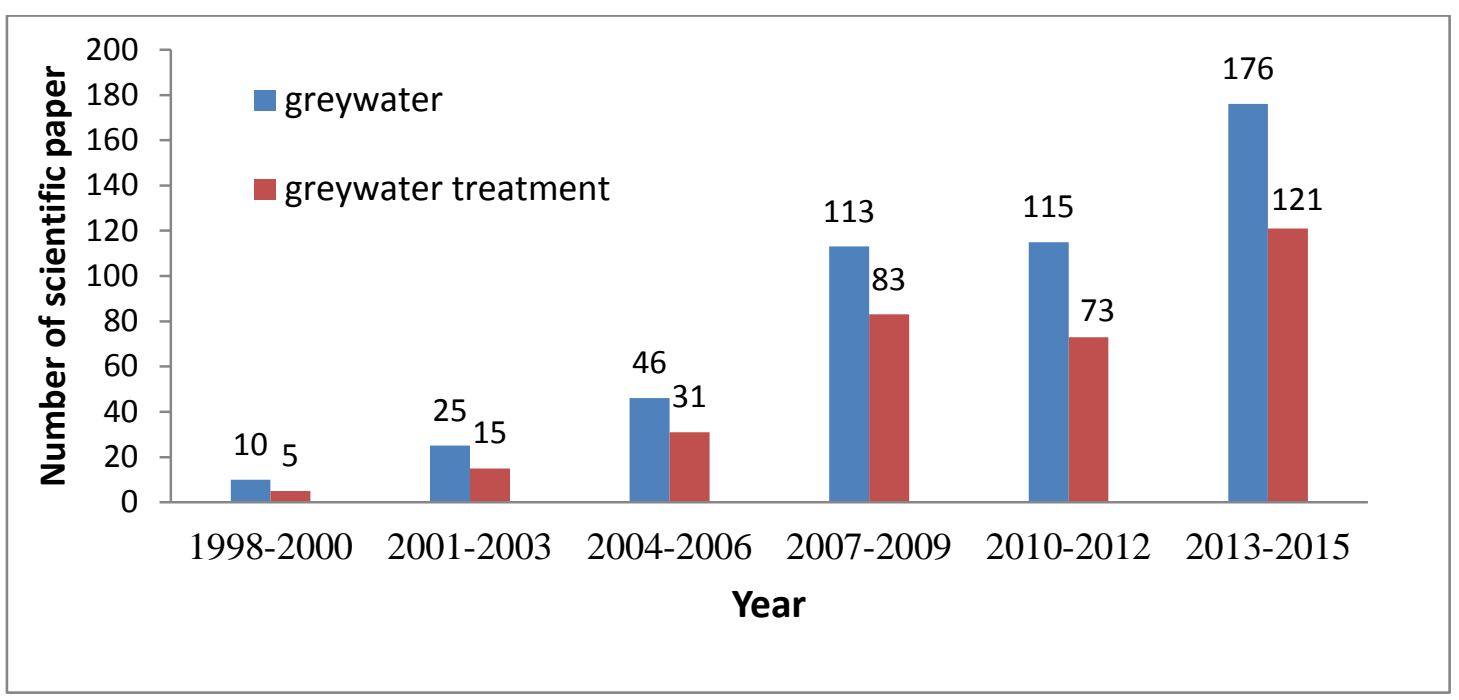

Figure 3: Number of published papers in the Web of Science database

Technologies used for greywater treatment are classified based on treatment principle, and can be divided into physical, chemical, and biological systems, or a combination of these (Li et al., 2009; Ghunmi et al., 2011; Boyjoo et al., 2013). Most of these technologies are preceded by three different treatment steps: pre-treatment, main treatment, and post-treatment, as shown in Figure 4. To avoid clogging the subsequent treatment, pre-treatment options such as septic tank, filter bags, screens, and filters are used to reduce the amount of particles and oil and grease (Li et al., 2009). Whereas, the disinfection step as post-treatment is used to meet the microbiological requirements.

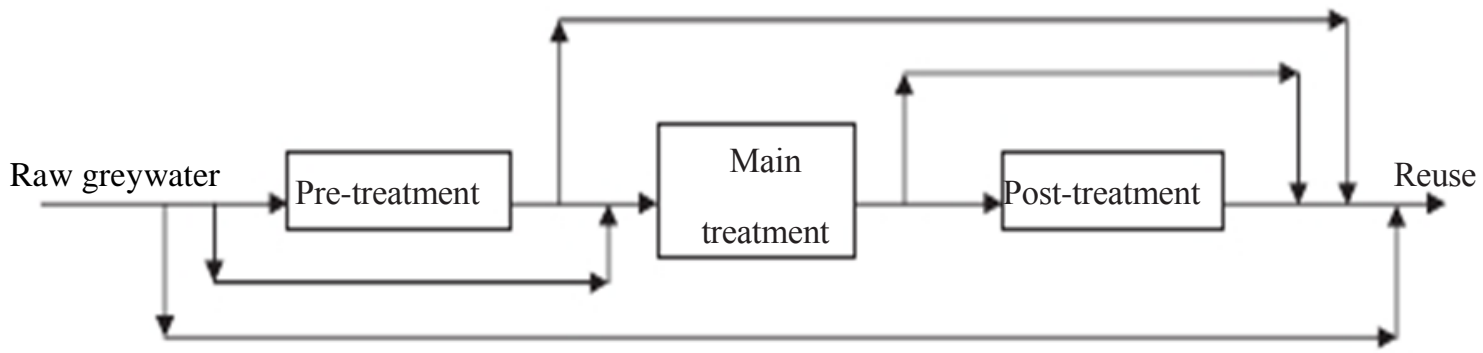

Reference: Ghunmi et al. (2011)

Figure 4: Graywater recycling and treatment: possible steps and tracks

The greywater treatment systems in the literature were reviewed and the main results indicate that: 


\subsection{BIOLOGICAL GREYWATER TREATMENT SYSTEMS}

Several biological treatment systems have been applied for greywater treatment, including Rotating Biological Contactor (RBC), Sequencing Batch Reactor (SBR), Membrane Bioreactors (MBR),Fluidized Bed Reactor (FBR), and Upflow Anaerobic Sludge Blanket (UASB). Biological systems are usually preceded by a coarse filtration pre-treatment stage and followed by sedimentation/filtration to remove biosolids or sludge, and a disinfection post-treatment stage by chlorination or UV to remove microorganisms (Boyjoo et al., 2013). Aerobic biological processes are able to achieve excellent organic and turbidity removal rates. After aerobic biological greywater treatment processes, most of the biodegradable organic substances are removed and consequently microorganism re-growth and odor problems are avoided, making the treated greywater more stable for storage over longer periods. Hence, medium to high strength greywater is suggested for treatment using biological processes (Li et al., 2009).

The MBR combines biodegradation with membrane filtration for solid liquid separation. The MBR has been regarded as an innovative technology for greywater treatment since it is the only technology that can achieve satisfactory removal efficiencies of organic substances, surfactants, and microbial contaminations without the need for the post-filtration and disinfection steps. MBR systems achieved efficient removal rates: turbidity (98-99.9\%), TSS (around 100\%), BOD (93-97\%), COD (86-99\%), total N (52-63\%), $\mathrm{PO}_{4-\mathrm{P}}(10-40 \%)$, total P (19\%), and FC (99.9\%); (Ghaitidak and Yadav, 2013). The qualities of the MBR effluent complied with various reuse standards (Pidou et al., 2007; Boyjoo et al., 2013; Bani-Melhem et al., 2015). Because MBR produces excellent and stable effluent quality and a high organic loading rate, has a compact structure and low excess sludge production, it appears to be an attractive technical solution for greywater recycling, particularly in collective urban residential buildings (Lazarova et al., 2003). Friedler and Hadari (2006) found that on-site MBR-based greywater treatment systems can be economically realistic and feasible when the building size exceeds 37 storiess. Lazarova et al. (2003) estimated that the annual capital and operational costs of the MBR greywater treatment system can drop to $1.7 € / \mathrm{m}^{3}$ for installations serving more than 500 inhabitants. Merz et al. (2007) reported that the MBR investment and operational costs are high and thus less affordable for developing countries. Reducing investment and operating costs for a reasonable payback period is still an unsolved problem for single-household MBR applications (Jabornig and Podmirseg, 2015).

The RBC and FBR were found to be efficient at treating light greywater (Nolde, 2000). Nolde (2000) found that the effiuent BOD concentration was always less than $5 \mathrm{mg} \mathrm{L}^{-1}$ when using the $\mathrm{RBC}$ and FBR to treat shower, bath, and/or washbasin greywater that had initial BOD concentrations in the range of 50-250 and 70-300 $\mathrm{mg} \mathrm{L}^{-1}$, respectively. Friedler et al. (2006) obtained very high quality RBC effluent by treating light greywater with initial BOD and COD concentrations of 59 and $158 \mathrm{mg} \mathrm{L}^{-1}$, respectively. The $\mathrm{RBC}$ requires lower maintenance if the number of stages are increased (while keeping the same volume; Nolde (2000)). The RBC is more efficient at removing BOD than COD (Friedler et al., 2006), and was also found to remove micropollutants (Eriksson and Donner, 2009).

SBR is a special form of activated sludge processing in which all of the treatment processes takes place in the reactor tank. SBR performs equalization, biological treatment, and secondary 
clarification in a single tank, using a time-controlled sequence. It is one of the technologies for the removal of conventional parameters in small communities. Effluent from SBR treatment (Lamine et al., 2007) of shower greywater meets the $\mathrm{NH}_{4}-\mathrm{N}, \mathrm{BOD}$, and COD standards for wastewater reuse; BOD removal varied from 80 to $98 \%$ and similar ranges of COD removal were observed. The Hydraulic Retention Time (HRT) required 36 hours to achieving this level of efficiency, which is very high but unfortunately impractical for real-world applications. The performance of SBR systems for reuse parameters like turbidity, TSS, TC, FC, and E.coli were not tested (Ghaitidak and Yadav, 2013).

The poor removal efficiencies of both organic substances and surfactants make anaerobic treatment unsuitable for greywater recycling (Leal et al., 2011). Only 40\% COD removal was achieved using an HRT with a UASB for 12-24 hours, compared to 90\% COD removal using an aerobic FBR of similar volumetric size (Leal et al., 2011). The removal of TN and TP was 21.7$29.8 \%$ and 15.2-20.6\%, respectively, for the UASB (Elmitwalli and Otterpohl, 2007). Nevertheless, good treatment can be achieved if anaerobic treatment is used as pre-treatment and combined with aerobic treatment (Ghunmi et al., 2011); however, proper insulation and effluent disinfection are required. Anaerobic treatment is low cost and simple (Halalsheh et al., 2008), but aerobic treatment was better than anaerobic treatment at theremoval of toxic effects in greywater (Leal et al., 2011).

\subsection{PHYSICAL GREYWATER TREATMENT SYSTEMS}

Physical greywater treatment systems include filtration and sedimentation. Filtration is usually used as a pre-treatment method (i.e., before biological or chemical treatment) or as a posttreatment method (i.e., prior to disinfection). Filtration as a pre-treatment method includes screen meshes, sand bed filtration, nylon sock type filtration, metal strainers, gravel filtration, and mulch tower system (Boyjoo et al., 2013). Solely using physical greywater treatment processes as the main treatment method is insufficient for greywater treatment, since it does not guarantee adequate reduction of organics, nutrients, and surfactants, except in situations where the organic strength is extremely low (Li et al., 2009; Ghunmi et al., 2011; Boyjoo et al., 2013; Ghaitidak and Yadav, 2013). The efficiency of the filtration techniques depends on the distribution of greywater particle size pollutants and the filters' porosity; in general, the smaller the filters' porosity the better the effluent quality. Hence, coarse filters have limited effect on the removal of the pollutants present in the greywater (Li et al., 2009; Ghunmi et al., 2011; Boyjoo et al., 2013; Ghaitidak and Yadav, 2013).

Chaillou et al. (2011) investigated the potential of a sand bed filter to treat bathroom greywater. A mean removal of $30 \% \mathrm{COD}$ and a maximum E. coli removal of two log CFU/100 mL was observed. Similarly, Zuma et al. (2009) observed that a mulch tower system consisting of mulch, coarse sand, fine gravel, and coarse gravel removed 26\% of COD and 52\% of TSS while the level of FC and total coliforms remained unchanged. Membrane filtration (i.e.,metal-made membranes; Kim et al. (2007)), microfiltration (MF), ultrafiltration (UF) and nanofiltration (NF; (Shin et al., 1998; Ramona et al., 2004)) produce a high quality effluent that is proportional to the molecular weight cut-off (MWCO) of the membrane. UF membranes with pores in the range $30-200 \mathrm{kDa}$ have beenreported to filter between $92-97 \%$ and $45-70 \%$ of turbidity and organic matter, respectively. The permeate obtained with NF membranes is of even better quality, as they 
remove soluble organic matter, ionic species, pathogens, and even viruses (Ramona et al., 2004). Ramona et al. (2004) treated shower water via NF, and the removal of COD, TOC, and soluble ionic species was 93\%, 84\%, and 50\%, respectively, resulting in a permeate quality well suited for all-purpose unrestricted reuse.

Filters face a number of operational problems such as cleaning frequency. Furthermore, membrane foling and its consequences for operating and maintenance costs can restrict the widespread application of membrane technologies for greywater treatment. The pre-treatment of raw greywater in storage and settling tanks partially mitigates the clogging problems associated with sand filters. Whereas, membrane filtration (i.e., micro-, ultra-, and nanofilters) could be an option for post-treating greywater to achieve the most conservative standards (Li et al., 2009; Ghaitidak and Yadav, 2013).

\subsection{CHEMICAL GREYWATER TREATMENT SYSTEMS}

The chemical greywater treatment systems used in greywater treatment include coagulation and flocculation, electrocoagulation, adsorption using granular activated carbon (GAC) and natural zeolites, magnetic ion exchange resin (MIEX), powdered activated carbon (PAC) and advanced oxidation processes (AOPs) such as ozonation, and photocatalysis (Li et al., 2009; Boyjoo et al., 2013). These systems are efficient for use with light greywater and, in some cases, laundry greywater. In comparison with the physical processes, the chemical processes are able to reduce organic substance and turbidity in greywater to certain degree but not sufficient to meet the nonpotable reuse standards, especially for high strength greywater (Li et al., 2009; Boyjoo et al., 2013).

Pidou et al. (2008) investigated the use of a coagulation/flocculation treatment system for shower greywater. They achieved sufficient levels of organics and coliforms removal but found poor in removal of total $\mathrm{N}$; they achieved BOD removal of 85 to $89 \%$,COD removal around $64 \%$, total $\mathrm{N}$ removal of up to $13 \%$, TC removal $>99 \%$, and E. coli removal $>99 \%$. Furthermore, this system provided better results in acidic $\mathrm{pH}$, which requires adjusting the $\mathrm{pH}$ after treatment. Adjustment of $\mathrm{pH}$ before and after treatment would increase the cost of the system (Ghaitidak and Yadav, 2013). A flocculation system using aluminium sulphate (Kariuki et al., 2011) had no effect on $\mathrm{pH}$, salinity, and electrical conductivity in both kitchen and laundry greywater. Flocculated greywater could not meet any of the reuse standards, except $\mathrm{pH}$.

In Taiwan, electrocoagulation was effective at treating shower water from a building (Lin et al., 2005). The coagulant was produced from the evolution of $\mathrm{Al}^{+3}$ at the aluminium anodes. Hydrogen was produced at the cathodes and the bubbles allowed the particles to float, which were skimmed out in a separate vessel. Disinfection with sodium hypochlorate was required to eliminate all E. coli in the greywater. The water quality obtained satisfied general guidelines for non potable reuse. The system capacity was $28 \mathrm{~m}^{3} \mathrm{~d}^{-1}$, had a footprint of only $8 \mathrm{~m}^{2}$, and a total cost of US $\$ 0.27 \mathrm{~m}^{-3}$, which was below the local potable water rate (Lin et al., 2005).

Photocatalysis with titanium dioxide $\left(\mathrm{TiO}_{2}\right)$ catalysts was an efficient post-treatment method for biological systems (Li et al., 2004; Gulyas et al., 2007). Photocatalysis is the use of a catalyst, UV light, and an oxidant to oxidize organic pollutants in air or water. The disinfection step is not 
required, as photocatalysis can greatly reduce pathogens in water (Li et al., 2004). Sanchez et al. (2010) successfully obtained a 65\% dissolved organic carbon removal rate from hotel light greywater using photocatalysis. However, the effluent was treated with $\mathrm{TiO}_{2}$ and thus needed further treatment to remove the $\mathrm{TiO}_{2}$, and this makes the disinfection process expensive (Ghunmi et al., 2011).

Based on the literatures, it was found that chemical processes such as coagulation, followed by a filtration and/or disinfection stage, can reduce the suspended solids, organic substances, and surfactants in low-strength greywater to an acceptable level that can meet non-potable urban reuse needs (Lin et al., 2005; Pidou et al., 2008). However, for medium- and high-strength greywater, the reclaimed water that is produced from chemical processes is not always able to meet the required reuse standards in all situations, unless these processes are combined with other processes (Pidou et al., 2008). The effluent from the chemical processes can be either polished by a sand filtration stage to meet restricted non-potable urban reuse standards, or further treated by a membrane filtration stage to reach non-restricted reuse standards. The effluent from the sand filtration stage shall be disinfected to meet non-restricted reuse standards (Li et al., 2009; Ghaitidak and Yadav, 2013). Chemical solutions are especially attractive for single household low-strength greywater treatment systems, as the variability in the strength and flow of the greywater did not affect their treatment performance (Pidou et al., 2008).

\subsection{NATURAL GREYWATER TREATMENT SYSTEMS}

Natural greywater treatment systems are extended systems that use natural media for filtration and biological degradation (e.g., soil and plants). They can be used for dark greywater treatment but a disinfection stage is required if a low pathogen effluent is wanted (Boyjoo et al., 2013). Some examples are sand filter, horizontal-flow constructed wetland (HFCW), vertical-flow constructed wetland (VFCW), anaerobic filters, and vertical-flow filter (VFF). These systems combine physical processes such as filtration through a filter medium (e.g., sand, gravel, rocks, cinder) with biological processes such as aerobic or anaerobic degradation via microorganisms found within the system (e.g., biofilm, plant roots, slugs, earth- worms). Chemical precipitation and adsorption processes are also believed to take place (Kivaisi, 2001). Nutrient uptake in planted systems (i.e., VFCW, HFCW) assists in the removal of nutrients such as phosphorus and nitrogen.

In terms of treatment performance and operating and maintenance costs, the constructed wetland can be regarded as the most environmentally-friendly and cost-effective technology for greywater treatment and reuses (Li et al., 2009; Ghaitidak and Yadav, 2013). They are considered preferable, mainly in LICs and middle income countries (MICs), due to their low cost (Boyjoo et al., 2013). However, they also require a large surface area (0.5-3 $\mathrm{m}^{2}$ person $^{-1}$; Paulo et al. (2009)). Therefore, they are not suitable for use in urban areas. Constructed wetland treatment systems achieved TSS removal rates of $90-98 \%$, BOD $>99 \%$, COD from 81 to $82 \%$, total $\mathrm{N}$ from 26 to $82 \%$, B from 0 to $63 \%$, and $\mathrm{K}$ up to $67 \%$. No removal was observed for $\mathrm{Ca}, \mathrm{Mg}$, and $\mathrm{Na}$. EC was found to increase in all constructed wetland technologies (Ghaitidak and Yadav, 2013). 
Winward et al. (2008) pointed that the vertical flow reedbed (RVFCW) was better at removing pathogens than horizontal flow reedbeds (RHFCW). The quality of the effluent can be improved if the system is operated with recirculation (Gross et al., 2007). There were no significant differences between planted and unplanted VFCW systems for most constituents removal. Both had good performance, and the simplicity of the system makes this treatment process a very attractive one (Manjate et al., 2015). Morover, the payback period of the RVFCW was about three years, and the system can be run and maintained by unskilled operators (Ghaitidak and Yadav, 2013). Pre-treatment of greywater will increase the size and volume of RVFCWs and may enhance removal of $P$. Constructed wetlands could meet most of the world's reuse standards for $\mathrm{pH}, \mathrm{BOD}$ and TSS. There is a need for post-treatment of the CW effluent to remove As, EC, E. coli, and Helminth eggs to make it fit for various reuse applications (Gross et al., 2007; Li et al., 2009; Ghaitidak and Yadav, 2013).

Furthermore, constructed mini wetlands (i.e., small-scale constructed wetland system (SSWL)) were found to be effective at removing contaminants and suitable for treating greywater sources (Wurochekke et al., 2015). SSWL is designed on ecological principles. The goal is to maximize the function of relevant ecological processes within a limited area. Wallace and Knight (2006) differentiated SSWLs from large-scale constructed wetland systems with regards to the operations and maintenance. Unlike the large-scale constructed wetland, the SSWL cannot afford the services of a full-time dedicated operations and maintenance (O\&M) staff. Most SSWLs rely on periodic visits by a system operator. SSWLs are held to the same effluent standards as large-scale treatment works, and must be simple and robust in order to operate continually with minimal attention. Hence, the SSWL must: produce a consistent effluent quality despite variable flow and loading rate, operate without constant tweaking and adjustment, minimize the use of mechanical equipment, and finally, be constructed out of local materials, especially in developing countries (Wallace and Knight, 2006). In view of future applications of SSWLs, further explorations should consider the selection of bed media grain size, use of aquatic plants, disinfection systems, and the design must consider local conditions such as temperature, rainfall, and greywater composition in order to achieve more efficient treatment (Dallas et al., 2004; Wurochekke et al., 2014).

\section{PROPOSED GREYWATER RECYCLING SCHEME FOR AGRICULTURAL IRRIGATION REUSES}

Based on the above review of greywater characteristics, guidelines requirements, and greywater treatment technologies, a greywater recycling scheme for agricultural irrigation reuse purposes was developed, without consideration of the economic feasibility of the treatment method (Figure 5). Our scheme is based on the Li et al. (2009) scheme of greywater recycling for nonpotable urban reuses (Figure 6). Li et al. defined unrestricted greywater reuse as ornamental fountains, recreational impoundments, lakes and ponds for swimming, toilet flushing, laundry, air conditioning, landscape irrigation, fire protection, construction, surface irrigation of food crops and vegetables (consumed uncooked), and street washing. Whereas the restricted greywater reuse include lakes and ponds for recreational uses (without body contact), landscape irrigation: where public access is infrequent and controlled, such as subsurface irrigation of nonfood crops and food crops and vegetables that are consumed after processing (Li et al., 2009). 
As shown in the greywater recycling scheme for agricultural irrigation reuse purposes ( Figure 5), the greywater shall be equalized in a storage tank to cope with the variability in influent. The larger particles, hair, oil, and grease shall be removed before feeding it into the subsequent treatment processes ( $\mathrm{Li}$ et al., 2009). Chemical solutions (e.g., coagulation and ion exchange) followed by membrane filtration can be applied for the treatment of the low-strength greywater to meet the requirements of restricted and unrestricted agricultural irrigation. Alternatively, effluent from the chemical processes can be further polished by sand filtration in order to meet restricted agricultural irrigation requirements (this scenario depends on the microbial requirements in the given standard). After the disinfection of the effluent in the sand filtration step, the quality of the reclaimed greywater will thus meet the requirements of both restricted and unrestricted agricultural irrigation.

For medium- and high-strength greywater, the appropriate biological processes such as RBC, $\mathrm{SBR}$, and constructed wetlands can be used to remove organic substances in greywater. Any of these processes could be attached to the membrane filtration post-treatment, allowing the effluent to meet the requirements of restricted and unrestricted agricultural irrigation. Alternatively, sand filtration post-treatment followed by a disinfection step can be applied to meet the requirements of unrestricted and restricted agricultural irrigation. Sand filtration effluent without the disinfection step might meet restricted agricultural irrigation requirements (depending on the microbial requirements in the standard in question). Moreover, medium- and high-strength greywater can also be treated by the MBR to meet the requirements of both restricted and unrestricted agricultural irrigation.

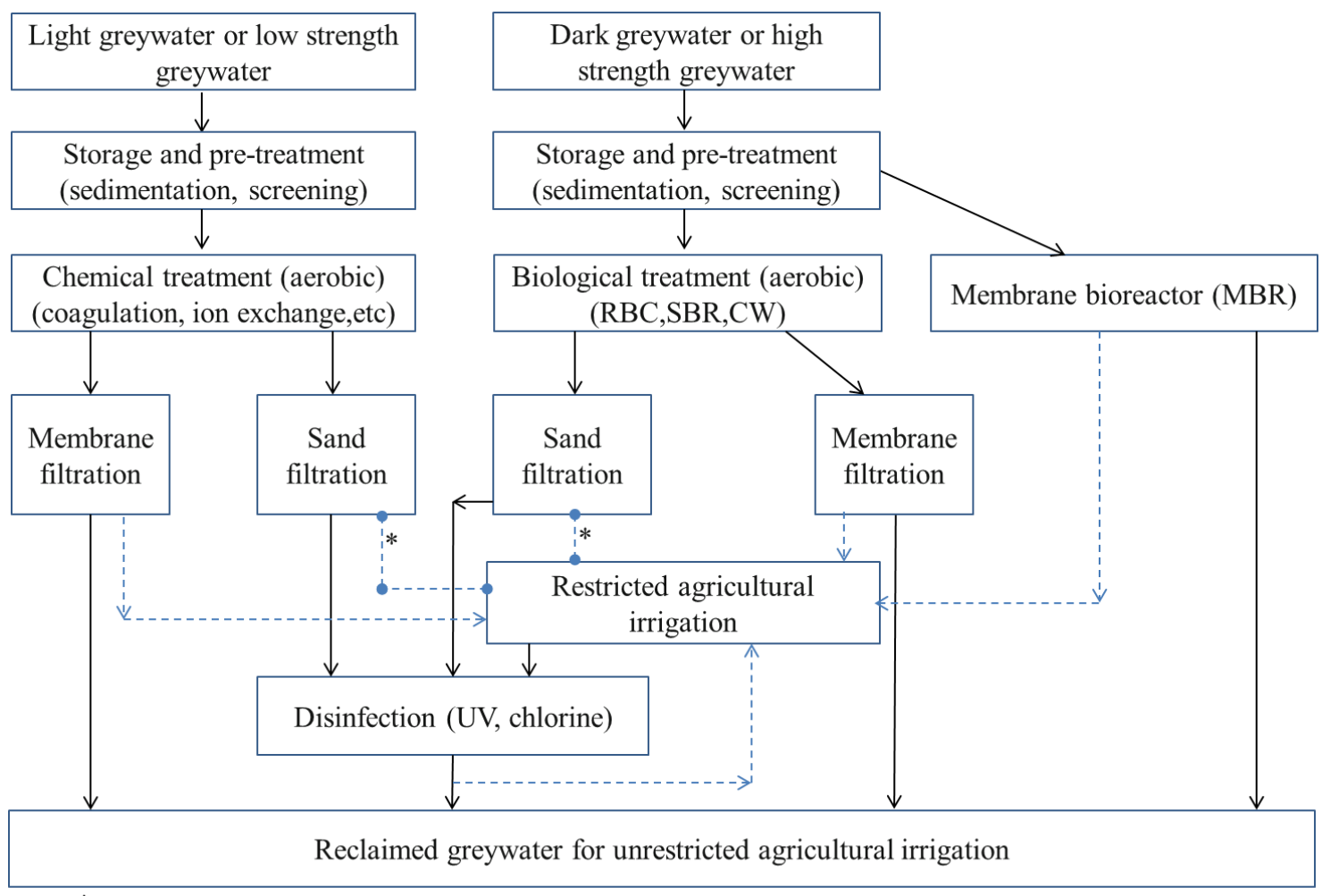

* Depend on the microbial requirements in the adapted standard

Figure 5: Possible greywater recycling scheme for agricultural irrigation reuse purposes 


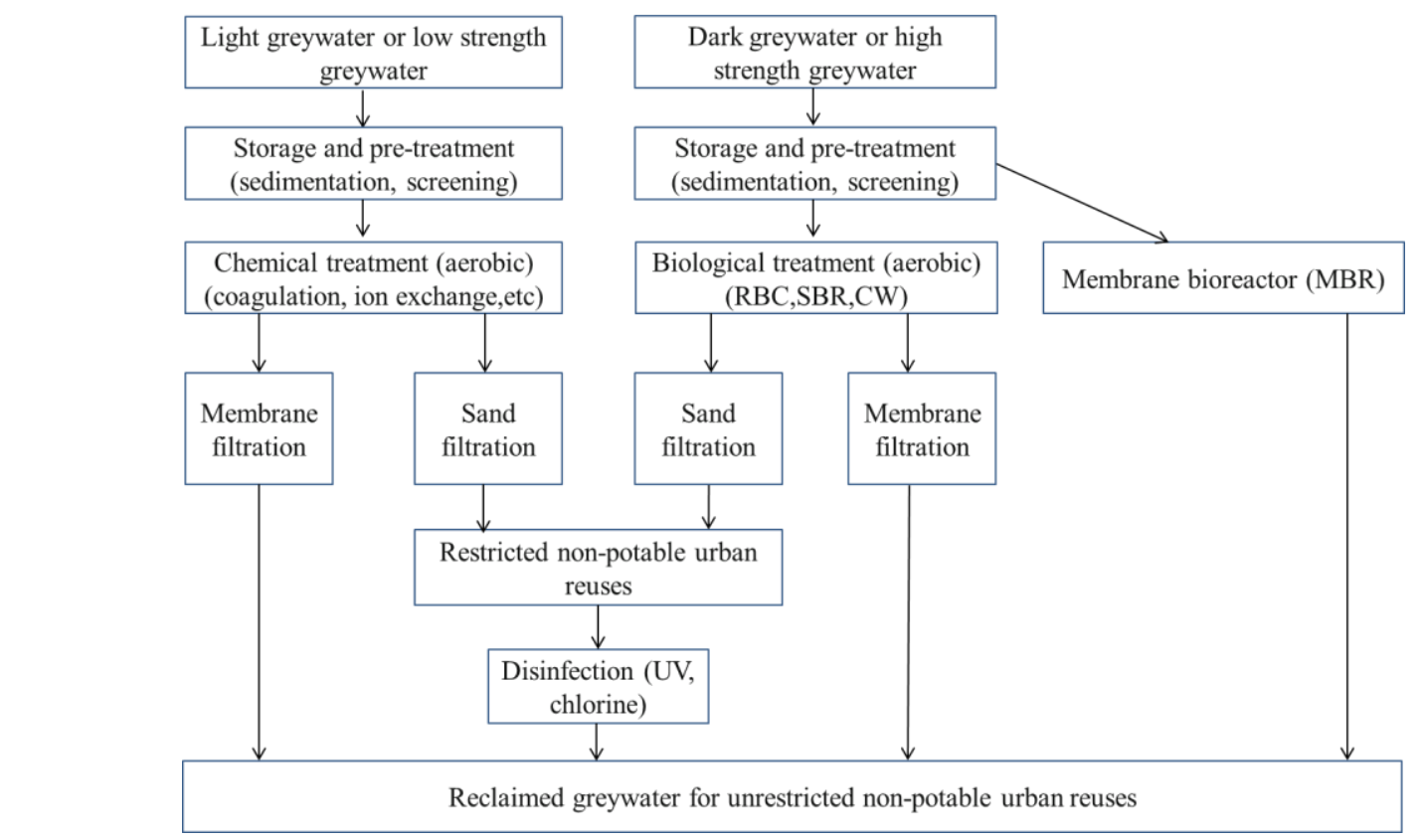

Reference: (Li et al., 2009)

Figure 6: The greywater recycling scheme for non-potable urban reuse purposes

\section{REFERENCES}

[1] Agency-UK, E., 2011. Greywater for domestic users: an information guide. Published by environmental agency. Available at: www.enviroment-agency.gov.uk.

[2] Al-Hamaiedeh, H., Bino, M., 2010. Effect of treated grey water reuse in irrigation on soil and plants. Desalination 256, 115-119.

[3] Al-Jayyousi, O.R., 2003. Greywater reuse: towards sustainable water management. Desalination 156, 181-192.

[4] Al-Mughalles, M.H., Rahman, R.A., Suja, F.B., Mahmud, M., Jalil, N., 2012. Household greywater quantity and quality in Sana'a, Yemen. EJGE 17, 1025-1034.

[5] Assayed, A., 2014. Development of a new and innovative greywater treatment technique for urban agriculture: Drawer Compacted Sand Filter, (Ph.D Dissertation), University of Surrey.

[6] Bani-Melhem, K., Al-Qodah, Z., Al-Shannag, M., Qasaimeh, A., Qtaishat, M.R., Alkasrawi, M., 2015. On the performance of real grey water treatment using a submerged membrane bioreactor system. Journal of Membrane Science 476, 40-49.

[7] Bartram, J., Fewtrell, L., Stenström, T.-A., 2001. Harmonised assessment of risk and risk management for water-related infectious disease: an overview. Water quality: Guidelines, standards and health, 1-16.

[8] Bino, M., Al-Beiruti, S., Ayesh, M., McIlwaine, S., Redwood, M., 2010. Greywater use in rural home gardens in Karak, Jordan. Greywater use in the Middle East: technical, social, economic and policy issues. The International Development Research Centre (IDRC) and the Center for the Study of the Built Environment (CSBE) International Meeting on Graywater Use, Aqaba, Jordan, February 2007. Practical Action Publishing, pp. 29-58. 
[9] Birks, R., Hills, S., 2007. Characterisation of indicator organisms and pathogens in domestic greywater for recycling. Environmental monitoring and assessment 129, 61-69.

[10] Boyjoo, Y., Pareek, V.K., Ang, M., 2013. A review of greywater characteristics and treatment processes. Water Science \& Technology 67, 1403-1424.

[11] Casanova, L.M., Little, V., Frye, R.J., Gerba, C.P., 2001. A SURVEY OF THE MICROBIAL QUALITY OF RECYCLED HOUSEHOLD GRAYWATERI. Wiley Online Library.

[12] Chaillou, K., Gérente, C., Andrès, Y., Wolbert, D., 2011. Bathroom greywater characterization and potential treatments for reuse. Water, Air, \& Soil Pollution 215, 31 42.

[13] Chong, M.N., Cho, Y.J., Poh, P.E., Jin, B., 2015. Evaluation of Titanium dioxide photocatalytic technology for the treatment of reactive Black 5 dye in synthetic and real greywater effluents. Journal of Cleaner Production 89, 196-202.

[14] Christova-Boal, D., Eden, R.E., McFarlane, S., 1996. An investigation into greywater reuse for urban residential properties. Desalination 106, 391-397.

[15] Dalahmeh, S.S., Hylander, L.D., Vinneras, B., Pell, M., Oborn, I., Jonsson, H., 2011. Potential of organic filter materials for treating greywater to achieve irrigation quality: $a$ review. Water Science \& Technology 63, 1832-1840.

[16] Dallas, S., Scheffe, B., Ho, G., 2004. Reedbeds for greywater treatment-case study in Santa Elena-Monteverde, Costa Rica, Central America. Ecological Engineering 23, 5561.

[17] Drechsel, P., Mahjoub, O., Keraita, B., 2015. Social and Cultural Dimensions in Wastewater Use. Wastewater. Springer, pp. 75-92.

[18] Elmitwalli, T.A., Otterpohl, R., 2007. Anaerobic biodegradability and treatment of grey water in upflow anaerobic sludge blanket (UASB) reactor. Water Research 41, 13791387.

[19] Eriksson, E., Auffarth, K., Henze, M., Ledin, A., 2002. Characteristics of grey wastewater. Urban water 4, 85-104.

[20] Eriksson, E., Donner, E., 2009. Metals in greywater: sources, presence and removal efficiencies. Desalination 248, 271-278.

[21] Flowers, B., 2004. Domestic Water Conservation: Greywater, Rainwater and Other Innovations.

[22] Friedler, E., Hadari, M., 2006. Economic feasibility of on-site greywater reuse in multistorey buildings. Desalination 190, 221-234.

[23] Friedler, E., Kovalio, R., Ben-Zvi, A., 2006. Comparative study of the microbial quality of greywater treated by three on-site treatment systems. Environmental technology 27, 653-663.

[24] Ghaitidak, D.M., Yadav, K.D., 2013. Characteristics and treatment of greywater-A review. Environmental Science and Pollution Research 20, 2795-2809.

[25] Ghunmi, L., 2009. Characterization and treatment of grey water; options for (re) use. Wageningen Universiteit (Ph.D Dissertation), The Netherlands, ISBN 978-90-8585-3930 .

[26] Ghunmi, L.A., Zeeman, G., Fayyad, M., van Lier, J.B., 2011. Grey water treatment systems: A review. Critical reviews in environmental science and technology 41, 657698. 
[27] Gross, A., Shmueli, O., Ronen, Z., Raveh, E., 2007. Recycled vertical flow constructed wetland $(R V F C W)$ - a novel method of recycling greywater for irrigation in small communities and households. Chemosphere 66, 916-923.

[28] Gulyas, H., Choromanski, P., Furmanska, M., Muelling, N., Otterpohl, R., 2007. Photocatalytic oxidation of biologically treated greywater in the presence of powdered activated carbon. International Conference on Sustainable Sanitation, Food and Water Security for Latin America, Fortaleza, Brazil.

[29] Halalsheh, M., Dalahmeh, S., Sayed, M., Suleiman, W., Shareef, M., Mansour, M., Safi, M., 2008. Grey water characteristics and treatment options for rural areas in Jordan. Bioresource technology 99, 6635-6641.

[30] Harikumar, P., Mol, B., 2012. A Synoptic Study on the preparation of a liquid waste management plan for Kerala State, India. Environment and Natural Resources Research 2, $p 74$.

[31] Itayama, T., Kiji, M., Suetsugu, A., Tanaka, N., Saito, T., Iwami, N., Mizuochi, M., Inamori, Y., 2006. On site experiments of the slanted soil treatment systems for domestic gray water. Water Science \& Technology 53, 193-201.

[32] Jabornig, S., Podmirseg, S.M., 2015. A novel fixed fibre biofilm membrane process for on-site greywater reclamation requiring no fouling control. Biotechnology and bioengineering 112, 484-493.

[33] Jamrah, A., Al-Omari, A., Al-Qasem, L., Ghani, N.A., 2006. Assessment of availability and characteristics of greywater in Amman. Water international 31, 210-220.

[34] Jefferson, B., Laine, A., Parsons, S., Stephenson, T., Judd, S., 2000. Technologies for domestic wastewater recycling. Urban water 1, 285-292.

[35] Jefferson, B., Palmer, A., Jeffrey, P., Stuetz, R., Judd, S., 2004. Grey water characterisation and its impact on the selection and operation of technologies for urban reuse. Water Science \& Technology 50, 157-164.

[36] Jenssen, P., Vråle, L., 2003. Greywater treatment in combined biofilter/constructed wetlands in cold climate. C. Werner et al (2003) Ecosan-closing the loop, 2nd int. symp. Ecological sanitation, Lübeck, Germany, GTZ.

[37] JSMO, 2008. Jordan Standards and Metrology Organization (JSMO) (2008). Greywater Jordanian Standard JS:1776.

[38] Kariuki, F.W., Kotut, K., Nganga, V.G., 2011. The Potential of a low cost technology for the greywater treatment. Open Environmental Engineering Journal 4, 32-39.

[39] Kim, J., Song, I., Oh, H., Jong, J., Park, J., Choung, Y., 2009. A laboratory-scale graywater treatment system based on a membrane filtration and oxidation processcharacteristics of graywater from a residential complex. Desalination 238, 347-357.

[40] Kim, R.-H., Lee, S., Jeong, J., Lee, J.-H., Kim, Y.-K., 2007. Reuse of greywater and rainwater using fiber filter media and metal membrane. Desalination 202, 326-332.

[41] Kivaisi, A.K., 2001. The potential for constructed wetlands for wastewater treatment and reuse in developing countries: a review. Ecological engineering 16, 545-560.

[42] Knerr, H., Engelhart, M., Hansen, J., Sagawe, G., Knerr, H., Engelhart, M., 2008. Separated grey-and blackwater treatment by the KOMPLETT water recycling system-A possibility to close domestic water cycle. International IWA Conference Sanitation Challenge, New Sanitation Concepts an d Models of Governance, pp. 260-268.

[43] Lamine, M., Bousselmi, L., Ghrabi, A., 2007. Biological treatment of grey water using sequencing batch reactor. Desalination 215, 127-132. 
[44] Lazarova, V., Hills, S., Birks, R., 2003. Using recycled water for non-potable, urban uses: a review with particular reference to toilet flushing. Water Supply 3, 69-77.

[45] Leal, L.H., Temmink, H., Zeeman, G., Buisman, C., 2011. Characterization and anaerobic biodegradability of grey water. Desalination 270, 111-115.

[46] Lesjean, B., Gnirss, R., 2006. Grey water treatment with a membrane bioreactor operated at low SRT and low HRT. Desalination 199, 432-434.

[47] Li, F., Wichmann, K., Otterpohl, R., 2009. Review of the technological approaches for grey water treatment and reuses. Science of the Total Environment 407, 3439-3449.

[48] Li, Z., Gulyas, H., Jahn, M., Gajurel, D., Otterpohl, R., 2004. Greywater treatment by constructed wetlands in combination with TiO2-based photocatalytic oxidation for suburban and rural areas without sewer system. Water Science \& Technology 48, 101 106.

[49] Lin, C.-J., Lo, S.-L., Kuo, C.-Y., Wu, C.-H., 2005. Pilot-scale electrocoagulation with bipolar aluminum electrodes for on-site domestic greywater reuse. Journal of environmental engineering 131, 491-495.

[50] Maeda, M., Nakada, K., Kawamoto, K., Ikeda, M., 1996. Area-wide use of reclaimed water in Tokyo, Japan. Water Science and Technology 33, 51-57.

[51] Mandal, D., Labhasetwar, P., Dhone, S., Dubey, A.S., Shinde, G., Wate, S., 2011. Water conservation due to greywater treatment and reuse in urban setting with specific context to developing countries. Resources, Conservation and Recycling 55, 356-361.

[52] Manjate, E., Lana, L., Moraes, D., Vasconcellos, G., Maciel, G., Von Sperling, M., 2015. First stage of the French vertical flow constructed wetland system: experiments with the reduction of surface area and number of units. Journal of Water, Sanitation and Hygiene for Development 5, 50-55.

[53] March, J., Gual, M., Orozco, F., 2004. Experiences on greywater re-use for toilet flushing in a hotel (Mallorca Island, Spain). Desalination 164, 241-247.

[54] Merz, C., Scheumann, R., El Hamouri, B., Kraume, M., 2007. Membrane bioreactor technology for the treatment of greywater from a sports and leisure club. Desalination 215, 37-43.

[55] Metcalf, Eddy, 1991. Wastewater Engineering: Treatment disposal and Reuse. Irwin Mcgraw Hill.

[56] Morel, A., Diener, S., 2006. Greywater Management in Low an [ie And] Middle-income Countries: Review of Different Treatment Systems for Households Or Neighbourhoods. Sandec at Eawag.

[57] Noah, M., 2002. Graywater use still a gray area. Journal of environmental health 64, 22.

[58] Nolde, E., 2000. Greywater reuse systems for toilet flushing in multi-storey buildingsover ten years experience in Berlin. Urban water 1, 275-284.

[59] O’Toole, J., Sinclair, M., Malawaraarachchi, M., Hamilton, A., Barker, S.F., Leder, K., 2012. Microbial quality assessment of household greywater. Water research 46, 4301 4313.

[60] Palmquist, H., Hanceus, J., 2005. Hazardous substances in separately collected grey-and blackwater from ordinary Swedish households. Science of the Total Environment 348, 151-163.

[61] Paulo, P., Begosso, L., Pansonato, N., Shrestha, R., Boncz, M., 2009. Design and configuration criteria for wetland systems treating greywater. 
[62] Perth, 2008. Perth Grey Water . http://www.perthgreywater.com.au/about-perthgreywater.html. Accessed 19 November 2015.

[63] Pidou, M., Avery, L., Stephenson, T., Jeffrey, P., Parsons, S.A., Liu, S., Memon, F.A., Jefferson, B., 2008. Chemical solutions for greywater recycling. Chemosphere 71, 147155.

[64] Pidou, M., Memon, F.A., Stephenson, T., Jefferson, B., Jeffrey, P., 2007. Greywater recycling: treatment options and applications. Proceedings of the ICE-Engineering Sustainability 160, 119-131.

[65] Prathapar, S., Jamrah, A., Ahmed, M., Al Adawi, S., Al Sidairi, S., Al Harassi, A., 2005. Overcoming constraints in treated greywater reuse in Oman. Desalination 186, 177-186.

[66] Ramona, G., Green, M., Semiat, R., Dosoretz, C., 2004. Low strength graywater characterization and treatmentby direct membrane filtration. Desalination 170, 241-250.

[67] Sanchez, M., Rivero, M., Ortiz, I., 2010. Photocatalytic oxidation of grey water over titanium dioxide suspensions. Desalination 262, 141-146.

[68] Scheumann, R., Merz, C., Atasoy, E., Murat, S., Baban, A., ElHamouri, B., Kraume, M., 2007. Greywater treatment with membrane bioreactors: Comparison of three different reactors operated with synthetic and real greywater. Proceedings.

[69] Shin, H.-S., Lee, S.-M., Seo, I.-S., Kim, G.-O., Lim, K.-H., Song, J.-S., 1998. Pilot-scale $S B R$ and MF operation for the removal of organic and nitrogen compounds from greywater. Water science and technology 38, 80-88.

[70] Sinclair, R.G., 2010. Wastewater Irrigation and Health: Assessing and Mitigating Risk in Low-Income Countries.

[71] Uddin, S.M.N., Li, Z., Adamowski, J.F., Ulbrich, T., Mang, H.-P., Ryndin, R., Norvanchig, J., Lapegue, J., Wriege-Bechthold, A., Cheng, S., 2015. Feasibility of a 'greenhouse system'for household greywater treatment in nomadic-cultured communities in peri-urban Ger areas of Ulaanbaatar, Mongolia: an approach to reduce greywaterborne hazards and vulnerability. Journal of Cleaner Production.

[72] Wallace, S.D., Knight, R.L., 2006. Small-scale Constructed Wetland Treatment Systems: Feasibility, Design Criteria and $O \& M$ Requirements. IWA Publishing.

[73] WHO-guidelines, 2006. Guidelines for the Safe Use of Wastewater, Excreta and Greywater: Policy and regulatory aspects. World Health Organization.

[74] WHO, 2015. Sanitation safety planning: manual for safe use and disposal of wastewater, greywater and excreta.

[75] Winward, G.P., Avery, L.M., Frazer-Williams, R., Pidou, M., Jeffrey, P., Stephenson, T., Jefferson, B., 2008. A study of the microbial quality of grey water and an evaluation of treatment technologies for reuse. Ecological engineering 32, 187-197.

[76] Wurochekke, A.A., Harun, N.A., Mohamed, R.M.S.R., Kassim, A.H.B.M., 2014. Constructed Wetland of Lepironia Articulata for Household Greywater Treatment. APCBEE Procedia 10, 103-109.

[77] Wurochekke, A.A., Mohamed, R., Saphira, R.M., bin Mohd Kassim, A.H., 2015. Sustainable Extensive On-Site Constructed Wetland for some Bacteriological Reduction in Kitchen Greywater. Applied Mechanics and Materials. Trans Tech Publ, pp. 11991204.

[78] Zuma, B.M., Tandlich, R., Whittington-Jones, K.J., Burgess, J.E., 2009. Mulch tower treatment system Part I: Overall performance in greywater treatment. Desalination 242, $38-56$. 